\title{
७MONÇÕES
}

\section{CENTRAL AMERICAN MIGRANT CARAVANS AND THE US: investigating the consequences of overlooking the climate-displacement nexus}

AS CARAVANAS MIGRATÓRIAS DA AMÉRICA CENTRAL E OS EUA: uma investigação sobre as consequências de se negligenciar o nexo migração-clima

LAS CARAVANAS MIGRANTES CENTROAMERICANAS Y LOS EEUU: una investigación acerca de las consecuencias de ignorarse el nexo migración-clima

Rodrigo Führ Programa de Pós-Graduação em Relações Internacionais, Universidade de Brasília (UnB) Brasília, Distrito Federal, Brasil

E-mail: rodrigo.fuhr@aluno.unb.br Orcid: https://orcid.org/0000-0003-4453-6168

Ana Laura Anschau

Programa de Pós-Graduação em Estudos Estratégicos Internacionais, Universidade Federal do Rio Grande do Sul (UFRGS)

Porto Alegre, Rio Grande do Sul, Brasil E-mail: ana.anschau@ufrgs.br Orcid: https://orcid.org/0000-0003-1554-9488

Dra. Veronica Korber Gonçalves

Programa de Pós-Graduação em Estudos Estratégicos Internacionais, Universidade Federal do Rio Grande do Sul (UFRGS)

Porto Alegre, Rio Grande do Sul, Brasil

E-mail: veronica.goncalves@ufrgs.br Orcid: https://orcid.org/0000-0001-7144-4707 
Abstract: The objective of this paper is to reflect upon the political and analytical consequences of overlooking the climate-displacement nexus over the U.S. reaction to recent Central American migration, considering the literature on climate displacement and the U.S. historical relation to migration. Our analysis comprehends the beginning of the Central American migrants' caravans in 2017 until the end of 2020. The paper is built from a qualitative perspective of analysis, working with primary sources such as migration and climate data reports, presidential statements, and newspaper articles on the U.S migration policies to the Central American caravans, in which it was possible to identify political and humanitarian implications that arose through the use of anti-immigration discourses and the overlooking of a connection between climate change and forced migration. Refusing to characterize these migration flows as induced by climate change, and following categorizing them as conventional economic migration, allows the U.S. to take a more sovereigntist position to the detriment of assuming its international responsibility for climate change and climate migrants.

Keywords: Climate migration; Climate mobility; Central America.

Resumo: O objetivo desse artigo é de refletir sobre as consequências analíticas e políticas de se negligenciar o nexo entre clima e deslocamento no caso da resposta estadunidense aos recentes fluxos migratórios a partir da América Central, levando em consideração a literatura sobre migração climática e sobre a relação histórica dos EUA com migração internacional. Nossa análise compreende desde o período do início das caravanas migratórias da América Central, em 2017, até o final do ano de 2020. Utiliza-se uma metodologia qualitativa, trabalhando com fontes primárias como relatórios sobre clima e migração, declarações presidenciais, e artigos de jornais sobre as políticas migratórias dos EUA para as caravanas centro-americanas, onde é possível identificar implicações políticas e humanitárias que surgem a partir do uso de discursos antimigratórios e da desconsideração da relação entre mudanças climáticas e deslocamento forçado. A descaracterização desses fluxos migratórios como relacionados a fenômenos climáticos e a sua subsequente categorização como migração econômica convencional permite que os Estados Unidos assumam uma posição mais soberanista em detrimento de assumir a sua responsabilidade internacional em relação às mudanças climáticas e migrantes climáticos.

Palavras-chave: Migração climática; Mobilidade climática; América Central.

Resumen: El objetivo de este artículo es reflexionar sobre las consecuencias políticas y analíticas al ignorar el nexo entre migración-clima y la reacción de los Estados Unidos a la reciente migración centroamericana, considerando, en este sentido, la literatura sobre el desplazamiento climático y la relación histórica de los EE. UU hacia la migración. Nuestro análisis comprende el período desde el inicio de las caravanas de migrantes centroamericanos en 2017 hasta fines de 2020. El análisis es construido desde una perspectiva cualitativa. Se trabaja con fuentes primarias como informes de datos migratorios y climáticos, declaraciones presidenciales y artículos periodísticos sobre las políticas migratorias de Estados Unidos hacia las caravanas centroamericanas, en los cuales fue posible identificar las implicaciones políticas y humanitarias que surgieron a través del uso de discursos antiinmigrantes y el desdeño de la conexión entre el cambio climático y la migración forzada. La caracterización errónea de estos flujos migratorios no como una consecuencia climática pero sí como migración económica convencional permite una posición más soberana de los EE. UU, menoscabando su responsabilidad internacional por el cambio climático y los migrantes climáticos.

Palabras-clave: Migración climática; Movilidad climática; Centroamérica. 


\section{Recebido em}

04/11/2020.

Aceito em 12/07/2021. 


\section{INTRODUCTION}

United States former President Donald J. Trump's (2017-2020) anti-immigration rhetoric was well-known: a significant share of his nationalist campaign agenda was based on a stronger and more restricted southern border control (TRAROOR, 2019; BLITZER, 2019a, 2019b). During his administration, he put into motion an explicit political crusade against immigrants from the Global South. While his campaign was built on this anti-immigration narrative, the majority of the asylum seekers in the U.S. in 2019 were from Central American countries like Guatemala and El Salvador (UNITED NATIONS HIGH COMMISSIONER FOR REFUGEES - UNHCR, 2020). The U.S. Congress suggested that these high numbers were due to Central American "weak institutions and corrupt government officials, chronic poverty, rising levels of crime, and demand for illicit drugs, [...] insecurity and citizens' low levels of confidence in government institutions" (U.S. CONGRESS, 2019a, p. 2).

Available data, however, indicate that this may not be the whole scenario. Overlooked and denied by Trump's administration, climate change is among the factors for migration in Central America. Although it would be an overstatement to affirm that climate change is the single reason for outmigration in Central America, there are compelling reasons to affirm that it is an overlooked push factor.

For instance, some International Organizations operating in the region are increasingly reporting on this subject. According to the Economic Commission for Latin American and the Caribbean (ECLAC), migration in the region is driven not solely by violence and insecurity but by the harms of climate change and natural disasters (ECONOMIC COMMISSION FOR LATIN AMERICA AND THE CARIBBEAN - ECLAC, 2018). Reports regarding ecological patterns changes in Central America also reinforce this trend, especially those focused in its northern region. These environmental changes led to, among others, an increase in the frequency and intensity of disasters, to the reduction of crop productivity, and to food shortage, all of which 
can compel people to migrate (FOOD AND AGRICULTURE ORGANIZATION - FAO, 2017; RIGAUD et al., 2018).

It is not our intention to define what kind of role the climate plays in Central American migration. As the literature on environmental migration shows, it is a complex phenomenon (MCADAM, 2011), where disasters and the climate can act in various ways - sometimes even enforcing immobility and not displacement (BOAS et al., 2018). Hence, it would be more accurate to state the existence of a multicausal nexus (FAO, 2017; BOAS et al., 2018; INTERNATIONAL ORGANIZATION FOR MIGRATION - IOM, 2019a) for Central Americans' decision to migrate, in which the climate is one among other stressors.

Furthermore, we do not intend to reinforce the "self-perpetuating myth" (BOAS et al., 2019, p. 902) that some scholars and policy-makers are pursuing of framing climate migration as an automatic consequence of climate change, hence securitizing it and contributing to arguments for closed borders. Nevertheless, this should not prevent us from establishing a connection between climate change and the migration flows from Central American, because of the crucial political and analytical consequences that this nexus provides, especially considering how the U.S. has responded to it.

In this sense, the objective of this paper is to reflect upon the political and analytical consequences of overlooking the climate-displacement nexus. We firstly aim at interpreting the U.S. reaction to recent Central American migration, taking into account the literature about climate displacement and the U.S. historical relation to migration. Second, we seek to understand how the refusal of acknowledging the influence of climate change factors in these migration flows, and their following categorization as conventional economic migration, allows a more sovereigntist position to the detriment of the U.S. assuming its international responsibility for climate change and climate migrants.

Furthermore, we aspire to challenge the standard account on the International Relations discipline that sees this issue through a strictly formalist standpoint. We claim that we have much to gain for analyzing it through a climate change lens, considering the historical and political responsibilities of the states that caused the socioecological crisis we are facing. In this sense, we employ here the term "climate migration" instead of the overarching concept 
of "environmental migration" ${ }^{1}$ for a twofold rationale: (i) climate change is, although not the sole, a leading push factor for the migrant caravans; and (ii) "climate migration" eludes directly to the responsibility that developed countries hold for climate change, while the responsibility for the "environment" is only more loosely defined.

Our paper is built from a qualitative perspective of analysis, working with primary sources such as migration and climate data reports (e.g., INTEGRATED CARBON OBSERVATION SYSTEM - ICOS, 2020; ECKSTEIN; HUTFILS; WINGES, 2019; IDMC, 2020; UNITED NATIONS HIGH COMMISSIONER FOR REFUGEES - UNHCR, 2020; RIGAUD et al., 2018; RAINFOREST ALLIANCE, 2019), the US Customs and Border Protection data, presidential statements, and newspaper articles on the U.S migration policies to the Central American caravans, in which it was possible to identify the political and humanitarian implications that arose through the use of anti-immigration discourses and the overlooking of the connection between climate change and migration. Our analysis comprehends the beginning of the Central American migrants' caravans in 2017 until the end of Trump's administration, 2020.

The article is structured into three main sections. The first one provides an overview of the nexus between climate change and migration, considering how it can be a push factor for people to migrate in Central America. The following part analyses the U.S. relation with migration since its history is marked by migratory flows, aiming to show how the U.S. government rhetorically denies the climate aspect of Central American migration to render it as voluntary. The third section aims to reflect more in-depth on the political and analytical consequences of overlooking the climate-migration nexus, departing from the developed countries' responsibility for climate change and its consequences.

\footnotetext{
1 "Climate migration" is often defined as a subcategory of "environmental migration", which is a broader and more overarching term. For definitional aspects and discussions, see IOM (2019), Claro (2015), and Dun and Gemenne (2008).
} 


\section{CLIMATE CHANGE AND MIGRATION: AN OVERLOOKED NEXUS}

Climate change is often overlooked as a driver of migration. The International Refugee Law divides migrating people into two main groups: forcibly displaced (commonly called refugees) and voluntarily (or economic) migrants (BETTS, 2009). On a global scale, international law wrongly identifies those displaced by climate change as voluntary migrants, hence denying them the same array of protection as refugees have available (MCADAM, 2011; RAMOS, 2011; CLARO, 2015)². Nonetheless, as temperatures rise, several adverse effects of climate change affect human livelihoods, mainly in rural and poor areas, which often leads to population displacement (RIGAUD et al., 2018).

Jubilut et al. (2018) depicted six possible cases in which the environment can play a decisive role as a push factor for forced migration, the first two ${ }^{3}$ concerning climate change strictly:

(i) Migration related directly to climate change slow-onset adverse effects, such as in sea-level rise, droughts, Arctic and Patagonia glacial melting, biodiversity losses, and others;

(ii) Migration flows as a result of natural disasters, as the 2010 Haiti earthquake or cyclone storms that hit Central and North America.

These two examples above show how climate migration's flows relate distinctly to socioeconomic factors and to the nature of climate phenomena. That is, there is neither a single cause nor a response to it (MCADAM, 2011; JUBILUT et al., 2018). Nevertheless, all these scenarios may force people to migrate, thus supporting evidence that climate migrations may be forced rather than voluntary in specific situations (MCADAM, 2011).

\footnotetext{
2 Humanitarian and international actors have been proposing international norms that put into light the forced character of climate displacement. A noteworthy case here is the International Organization for Migration that, in its "Glossary on Migration" (IOM, 2019, pg. 31), highlights how climate migrants may be "oblige to leave their habitual place of residence, or choose to do so" due to climate change impacts. Variations of this conceptualization may be found in international policies such as the Global Compact on Migration, but it is not yet translated into a binding multilateral agreement.

3 The other four possible cases of "forced environmental migration" for Jubilut and colleagues (2018) are: (i) Flows resulted from technological disasters, such as the Mariana dam rupture (2015); (ii) Displacements as a result of grand development projects, such as the construction of power plants or river diversions; (iii) Flows derived from state-sponsored protection projects, such as in the creation of conservation units; and (iv) Displacement deriving from nuclear disasters or radiological accidents, as in Chernobyl, Fukushima, or the Brazilian case of Caesium-137 in Goiania.
} 
Climate migration is a multicausal and complex phenomenon involving many factors. We can illustrate this by outlining five of these complexities. First, people can migrate due to climate change internally or internationally. Second, the causes can be natural or anthropogenic or, more realistically, a mix of both. Third, weather events can be extreme, as in natural disasters, or arise from long-term slow degradation, as in desertification or biodiversity loss. Fourthly, these occurrences can also be temporary as in the case of seasonal droughts, or permanent as in sea-level rise in small island states. And finally, while in some specific situations climate change can be traced back as a major cause of migration, they are most of the times one factor among a multitude of others, operating interdependently with economic, cultural, racial, and other elements of displacement (MCADAM, 2011). The climate-migration relationship can be described as "a complex nexus" (IOM, 2019a) but needs to be better observed and conceptualized for being fully understood and addressed (DUN; GEMENNE, 2008; MCADAM, 2011; BOAS et al., 2019).

The Intergovernmental Panel on Climate Change (IPCC, 2007) has stated that current patterns of $\mathrm{CO} 2$ emissions will lead to an increase of slow and rapid-onset disasters, which will be a direct threat to humankind. Weather changes can also lead to crop yield reductions which, in turn, brings food insecurity, forcing people to move away from agriculture or, in most extreme cases, compelling them to migrate. Notwithstanding, every estimate of global environmental migration varies widely in its prediction and is contested in its methodology (MCADAM, 2011; IOM, 2019a). While early investigations had predicted an international displacement of 250 million people by 2050 (MYERS, 1993), later reports have reached the heights of one billion people by the end of the 21st century (STERN, 2007). Currently, the most widely cited forecast is that internationally displaced people by climate change will reach 200 million by 2050, following the International Organization for Migration (IOM), a United Nations-related agency (IOM, 2019a) ${ }^{4}$.

\footnotetext{
4 Another noteworthy forecast, published by the World Bank, expects up to 143 million climate migrants until 2050 in Latin America, Sub-Saharan Africa, and South Asia. This report is deemed conservative since it only analyses internal displacement, that is, migration flows not crossing national borders, besides considering only slow-onset impacts of climate change and disregarding other extreme events and natural disasters (RIGAUD et al., 2018).
} 
These figures differ mainly due to the struggle in predicting climate factors and human behavior. Jane McAdam (2011) affirmed that predicting human behavior is challenging in situations such as climate change and natural disasters owing to what she defined as "human resilience". External (i.e., environmental) triggers do not imply instantaneous displacement, as some people choose to migrate earlier while others decide to remain in place.

In other words, social, cultural, and economic ${ }^{5}$ factors may come into play affecting these people's decision to or not to migrate - a blurred line that makes these predictions open to contesting (Boas et al. 2019). Alongside future state-sponsored adaptation and mitigation plans, these individual preferences and conditions make prediction methods vary, and hence their estimates of migration flows vary too (MCADAM, 2011). Furthermore, these estimates are disputed by critical scholars who argue that their methodology is problematic and might be opening venues for authoritative politicians to securitize climate migration, putting forward a "self-perpetuating myth" on which climate change is framed as always automatically leading to increased migration (BOAS et al., 2019, p. 902).

Having analyzed some of the main trends of the literature on climate migration, it is now due to discuss how climate change relates to the Central American caravans. A recent report published in 2018 by the World Bank predicts a rise in between 1.4 and 3.9 million climate migrants in the region of Central America by 2050, accounting for $1.9 \%$ of its population. These numbers dramatically increase in the coming decades until the end of the century, mostly due to the lack of water availability and progressive decrease of rainfall necessary for crop productivity (RIGAUD et al., 2018). Notwithstanding, climate migration is not an isolated phenomenon in Central America. The last Global Report of the Internal Displacement Monitoring Center (IDMC) indicated that 23.9 million people were forcibly displaced in their own countries in 2019 by weather-related events, of which more than 900 thousand (almost 3\%) took place in the United States (IDMC, 2020).

\footnotetext{
5 Pigliucci (2019) added that another difficulty faced by climate migration projections is individual access to migration networks. Commonly, those who are more prone to be pushed to migrate due to climate change are poor; but a portion of the rural population, even poorer, struggle to migrate because they cannot afford relocation.
} 
Central America, especially in its Northern Triangle (Guatemala, Honduras, and El Salvador), is one of the sub-regions most prone to adverse effects of global climate change (ECKSTEIN; HUTFILS; WINGES, 2019). It covers hundreds of microclimates, from drylands in the far north near Mexico and the United States to rainforests in the south. The region is also marked by seasonality, with droughts and tropical storms followed by heavy rains and strong winds in the mountains (RIGAUD et al., 2018). Lately, such events have become irregular in time of the year, duration, and place of occurrence. Summer rains have occurred two to three months later than compared with the last decade, waning and concentrating within a short period. Moreover, drastic daytime temperature changes have also been observed, from a cold breeze at night to heat and dry waves in the daytime (BLITZER, 2019a; RAINFOREST ALLIANCE, 2019). In the years to come, meteorologists expect an even more significant reduction in precipitation during October and March, with more frequent and extreme El Niño events, meaning a possible drier climate in the south and a wetter one in the north (RIGAUD et al., 2018).

All these climate changes directly influence local socioeconomic conditions since over $30 \%$ of its population lives in rural areas, i.e., heavily agriculture-dependent regions. Its uneven seasonality has reduced farming production severely, as rains have come later than usual and temperature variation during the day makes it harder for crops to survive. Growing season shortening can further impact market prices of production, as harvesting is increasingly concentrated within a shorter period, raising competitiveness and lowering selling prices. Maize, beans, and rice are more dramatically affected by climate change and are staple crops grown for subsistence in the region. Declines in the production of these subsistence crops, particularly growing season shortening, have impacted food security in rural areas (SIVISACA et al., 2015). Indeed, the United Nations Food and Agriculture Organization (FAO) affirmed that most people living in Central America are food insecure (FAO, 2017), which may compel people to migrate.

The Dry Corridor is a Central American sub-region considered more susceptible to the long-term effects of slow-onset climatic changes (RIGAUD et al., 2018). It is a dry forest strip along the southernmost sections of Mexico to the north of Panama. More than $40 \%$ of its 
population lives in rural areas, reaching $60 \%$ in some parts. In Guatemala, El Salvador, Honduras, and Nicaragua, it is marked by severe droughts and rainfall reductions, with precipitation having dropped by $40 \%$ below expected in recent years. Most of its population lives below the poverty line, with limited access to basic infrastructure and hence vulnerable to weather variations (FAO, 2017). It is further characterized by its high unemployment rates and seasonal labor, related to growing and harvest seasons. As the climate becomes irregular, labor becomes uncertain, prompting a pattern of economic vulnerability (WFP, 2017; ECLAC, 2018). Some analysis claim that the Dry Corridor is expected to be one of the major hotspots of climate migration nowadays and in the future (RIGAUD et al., 2018; ABDENUR, 2019). This can be observed as the caravans of migrants witnessed in 2018 and 2019 originated from this subregion (MILMAN; HOLDEN; AGREN, 2018; TRAROOR, 2019).

These slow-onset effects of climate change thus may be a push factor for Central Americans to migrate. If observed jointly with sea-level rise in its coastal areas and with natural and anthropogenic disasters, such as cyclonic storms and other extreme events, the subcontinent is one of the most vulnerable to climate changes (RIGAUD et al., 2018), while it is one of the regions with lower pollutant emissions per capita (RAINFOREST ALLIANCE, 2019) ${ }^{6}$. Furthermore, the subregion holds a limited capacity to mitigate and adapt to climate change, bearing restricted resources to change this situation (RIGAUD et al., 2018).

The World Food Programme (WFP, 2017) posited that climate change, jointly with social and economic conditions (such as unemployment, violence, debts, and others), has become stressors for the population in Central America. However, they only turn into push factors for migration when all other "coping strategies" are eroded. They conducted a survey with emigrants from the Northern Triangle and found out that people only migrated as a last resource. People emigrating from rural areas in Central America first tended to reduce consumption and readjust their finances as resilience mechanisms, followed by a period of debt and sale of "non-livelihood assets" to, finally, sell its land or other productive assets.

\footnotetext{
${ }^{6}$ Guatemala, for instance, was the 14 th most affected country by extreme weather events in the last two decades, according to the Global Climate Risk Index 2019, whereas it has one of the least greenhouse gas emissions per capita worldwide (ECKSTEIN; HUTFILS; WINGLES, 2019).
} 
Displacement only happened as an "ultimate coping strategy" when no alternative was available (WFP, 2017).

Other surveys, as Sivisaca and colleagues' (2015, pg. 40), show similar results. In their study focusing on food security, climate change was identified as impacting Guatemalans diets and, both in short- and long-term situations, possibly leading to migration. This persistence in staying in their land until coping is no longer possible also suggests that climate migration can be forced and not voluntary. Moreover, it shows how human resilience plays a role in migration decision-making, encouraging people to remain in their homelands for as long as possible (MCADAM, 2011).

Social inequalities likewise mark climate migration in Central America. While women have migrated more now than in the last decades, reaching up to $20 \%$ of the total of Central Americans displaced in 2016 (WFP, 2017), climate displacement in the Northern Triangle is dominated by males. Women often stay in their homeland, taking care of children and crops, increasing their workload considerably in both domestic and production tasks (WFP, 2017; BLITZER, 2019a).

Debt is also a problem since, in rural areas, the decision to migrate is often made after households go into debt to increase crop yields by buying improved fertilizers or seeds (WERNICK, 2019). Once displacement is expensive, the decision to migrate comes with more loans and debt. These burdens are laid upon the responsibility of women and children until men arrive at the borders and start sending remittances that, in some cases, might not happen (BLITZER, 2019A; MARKHAM, 2019). Women have increasingly taken charge of households, especially in the Dry Corridor, which has been linked with a positive impact on food consumption, education, and family well-being - increasing women empowerment. This is even more common in situations where women are the ones managing remittances, enabling their children to receive proper education and employ resources more productively than do their male counterparts (WFP, 2017).

Another factor worth highlighting is that most of the climate displacement will occur within national borders, as, among other reasons, people expect environmental changes to be temporary and hence stay close to their homeland (RIGAUD et al., 2018). In the Central 
American region, not only will domestic migration increase but interregional displacement is also awaited. While people will likely leave coastal zones and regions most vulnerable to rainfall reductions (and therefore crop productivity), the urban areas in the Central Mexican Plateau and rural highlands in Guatemala will conceivably become hotspots for immigration (RIGAUD et al., 2018). Since these major cities are located in places with more favorable climate and better environmental conditions, they are expected to have increased immigration, which in turn may lead to the increase of population density and in itself generate a problem for "local and regional governmentality" (ALTAMIRANO, 2013, pg. 132). This scenario of regional displacement is already pushing governments to develop other sorts of governance practices based on South-South cooperation, even if insofar they have not reached a binding regulatory mechanism (MÉNDEZ, 2020).

In sum, factors such as high agricultural dependence, frequent extreme events (e.g., cyclone storms and earthquakes), vulnerability to slow-onset hazards, and the connection between climatic and socioeconomic stressors are all considered to increase migration in Central America in the upcoming decades. Nevertheless, migration to the United States will not be the strongest trend when it comes to climate migration in Central America - despite that, in 2019 only, more than four hundred thousand families were apprehended at the U.S. Southwest Border ${ }^{7}$, which encompassed more than quadruple the apprehensions from 2018 (U.S. CUSTOMS AND BORDER PROTECTION, 2021). And after arriving in the United States, Central American migrants come across a highly restrictive migration policy instead of being supported by public policies.

Thus, as climate change is a significant migration factor in Central America and the United States was the largest receiver of Central American asylum-seekers in 2019, we should briefly contextualize U.S. immigration history to analyze the actions of Trump's administration (2017-2020) toward Central American countries' immigrant and refugee policy.

\footnotetext{
${ }^{7}$ While the number of apprehensions cannot be used as direct evidence of migration flows, as there are other variables implied, they are often used as a proxy indicator of irregular migration, especially when used comparatively (WFP, 2017; ECLAC, 2018).
} 


\section{U.S. MIGRATION POLICIES' DOUBLE STANDARD PATTERN}

Over the years, U.S. immigration policies have been marked by contradictions and even hostilities. Migration regulations and laws have been historically biased towards some specific nationalities and increased the centralization of federal control over migratory flows (EWING, 2012). The end of the First World War had significant impacts on the United States, increasing European migratory flows. As a result, the first Emergency Quota Act (1921) was implemented in the same year, which imposed numerical limits, restricting general immigration and narrowing immigration from any country to $3 \%$ of the number of people already living in the United States (EWING, 2012).

The scenario experienced 26 years later, with the end of World War II, established a severe shortage of agricultural labor in the region, as many native men were summoned to act together with the Armed forces. In response to this, the U.S. government instituted the Bracero program (1942-1964), which transferred some 5 million temporary agricultural workers from Mexico to the United States, who often ended up working under slavery conditions. In the same period, the U.S. began to experience an exponential increase in the number of Mexican migrants, that immigrated without documentation or legal authorization. As such, the "Bracero" program was launched along with the "Wetback Operation" in 1954 to capture and deport about 1 million undocumented Mexican immigrants (EWING, 2012).

The creation of these programs highlights the beginning of a trend towards U.S. migration policy, which shows unequal treatment between welcome and unwelcome immigrants. While Mexican migrants were helpful to the state for working in agriculture under slave-like conditions, those who migrated to work in other sectors were seen as unwanted. Regarding this deportation policy, we should note that a few years earlier, in 1951, the United States demanded great efforts - both economic and cooperative - to establish the UN Convention relating to the Status of Refugee, founded on the principle of non-refoulement ${ }^{8}$. Since then, the United States commits itself to a double standard pattern:

\footnotetext{
8 The non-refoulement principle interdicts states from transferring or sending individuals to their original states if there is a risk to the person from suffering irreparable harm, as in human rights violations.
} 
anyone that does not fit the conventional refugee status is not welcomed, even though the U.S. economy is heavily dependent on the presence of these Latin American economic migrants.

The 1980s and 1990s were marked by an increase in immigration from Central America to the United States due to civil wars in El Salvador, Guatemala, and Nicaragua. Political and economic instability in the region tripled the number of immigrants displaced to the United States. Later, the occurrence of several natural disasters as hurricanes and earthquakes that devastated Central America led the U.S. to characterize Hondurans, Nicaraguans, and Salvadorans immigrants as eligible for Temporary Protected Status (TPS). The TPS granted nationals of these countries work authorization and prevented them from being deported (O'CONNOR; BATALOVA; BOLTER, 2019).

After the terrorist attacks of $9 / 11$, U.S. immigration policies were further tightened and used in the name of national security and the fight against terrorism. Within this period of the Bush administration, xenophobic speeches were intensified by implementing a special registration system for immigrants, who came to be directly linked to terrorist groups, that is, to those who supposedly pose an imminent threat to society (EWING, 2012). This xenophobic scenario of insecurity and dissatisfaction among the American people was used as a backdrop in the 2016 elections and helped to mark Donald Trump's rise to President of the United States.

Trump built his candidacy based on speeches focused on the need for states to protect themselves against the threat of "dangerous" immigrants, making it clear to his electorate that his government would be marked by a nationalist policy aimed at U.S. protection and development in search of the resumption international protagonism. In one of his first pronouncements, still as a candidate, he stated: "I would build a great wall, and nobody builds walls better than me, believe me, and I will build them very inexpensively, I will build a great wall on our southern border. And I will have Mexico pay for that wall" (TRUMP, 2015). This statement shows Trump's intention to close the southern U.S. borders to prevent new unwanted migrants from entering the country. 
Early in his tenure, Trump issued a series of executive orders promising significant changes to the U.S. immigration system, such as sharp cuts to immigration, reduction in illegal immigration, and expansion of the wall across the U.S.-Mexico border that initially began in 1994. During his tenure, Trump addressed Mexican immigrants as "criminals" and "rapists" and charged them for "stealing" job opportunities from Americans and "threatening" their lives (POWASKI, 2019), and hinted that "when Mexico sends its people, they are not sending their best [...]. They are sending people that have lots of problems, and they are bringing those problems to us. They are bringing drugs. They are bringing crime. They are rapists. And some, I assume, are good people" (LEE, 2015). These pronouncements show a trend of framing all migratory processes as economic migration, thus characterizing migrants as responsible for "stealing" Americans' jobs. However, the types of posts held by U.S. newcomer immigrants are found to be those that citizens themselves no longer apply for, i.e., obsolete vacancies (GARDNER, 2018).

The United States has never defined its national strategic immigration plans or priorities. The last significant immigration reform took place under the Immigration and Reform Act of 1986, which is perhaps why immigration has been a controversial political issue in the United States throughout its history. At the same time that Americans define their country as a nation of immigrants, they see immigrants as a threat to employment and security.

Historically, political goals, short-term thinking, and sometimes ad hoc decision-making have driven these selections. Faced with this dichotomy, the United States has turned its policy by selecting whom they allow entering this process and under what conditions (KUCZERA, 2017). Given this tendency to frame immigrants within economic lenses, human rights issues have been disregarded and disrespected; therefore, the state has been exempted from developing policies to welcome migrants and refugees. By framing climate migrants as economic migrants, the US gives them the same selective and utilitarian treatment.

Mass migration in Central America has reached new heights in the last few years. In 2019 alone, four hundred thousand migrant families were apprehended in US Borders, four times as much as in 2018 (US CUSTOMS AND BORDER PROTECTION, 2021). In 2018, Trump's 
government led this campaign to a new level by issuing a "zero-tolerance" policy against non-nationals who cross into U.S. territory through the Mexican border, even separating thousands of children from their families when in custody (BLITZER, 2019b). In addition, in July 2019, the White House reached a deal with the President of Guatemala, Jimmy Morales, to declare the Central American nation a "Safe Third Country", meaning that every U.S. asylum applicant could be denied if they did not apply for protection in Guatemala first, having already passed through that territory (WAGTENDONK, 2019).

The United Nations High Commissioner for Refugees' 2019 Global Trends showed that the United States was the largest receiver of asylum seekers during 2019, with more than 300.000 new requests. Furthermore, between 2018 and 2019, the total amount of border apprehensions increased more than 100\% (from 331.279 individuals to 700.997 ), including family apprehensions and individuals (US CUSTOMS AND BORDER PROTECTION, 2021).

The most controversial aspect of the Department of Justice (DOJ) and the Department of Homeland Security (DHS) "zero-tolerance" policy, however, is the separation of migrant children from their parents when taken into custody. In addition to violating human rights, this practice puts parents and children on different legal paths, making it difficult for the government to reunite families after parents' criminal prosecution ends (PIERCE; BOLTER; SELEE, 2018). In May 2020, for example, the Trump administration deported hundreds of migrant children alone, without notifying their families (DICKERSON, 2020).

According to Weiss (2019), instead of releasing resources to meet basic and urgent demands at border detention centers, or at least tackling the root causes of migration from Central America, Donald Trump has only sought to find outside culprits (WEISS, 2019). For example, in July 2019, in response to the widespread criticism he has received regarding detention centers, Trump used his Twitter to state, "If illegal immigrants are dissatisfied with the conditions, just tell them not to come. And all the problems are solved!" (CHANG-MUY; GARNICK, 2019).

Pierce, Bolter, and Selee (2018) affirm that, so far, none of the administrations in the U.S. modern history has placed such a high priority on immigration policy or had an almost exclusive focus on restricting "illegal" and unauthorized migratory flows. Trump's policies 
mark a shift in the way the U.S. discusses and manages immigration. Trump's administration expanded the scope of internal enforcement, drastically reduced refugee admissions, and shortened visa processing times. In short, Trump may not be able to rework the immigration system through laws, but his policy may significantly reduce immigration in practice (PIERCE; BOLTER; SELEE, 2018).

For some years, the United States has provided financial assistance for the development of Central American countries and reducing the flow of immigrants arriving in the United States from this region. In 2016, for example, the Obama administration announced $\$ 750$ million in funding to Honduras, Guatemala, and El Salvador through the Prosperity Alliance. However, this assistance was adjusted by the Trump administration, which cut many aid programs launched by previous governments (SIEFF; SHERIDAN, 2018). Trump's administration canceled another program in 2017: the "Climate, Nature and Communities of Guatemala", launched in 2014, was particularly successful in "helping rural Guatemalans respond to climate change through crop diversification, water conservation, and reforestation" (SIGELMANN, 2019, p. 9).

The cancellation of the financial aid to help combat the effects of climate change in the region shows that the US government is aware that climate change has negatively affected the region. Cutting development aid funds to Central American countries, however, tends to intensify problems at the U.S.-Mexico border, as it is one of the few foreign aid avenues available to governments facing extreme poverty and violence (CHANG-MUY; GARNICK, 2019).

\section{POLITICAL AND ANALYTICAL CONSEQUENCES OF OVERLOOKING THE CLIMATE-MIGRATION NEXUS}

To overlook the climate-migration nexus in the Central American caravans' flow to the U.S. has noteworthy political consequences. We can outline two: when states choose to overlook the climate as a reason for forced migration and thus wrongly categorize these migrant's status as voluntary, they deny the reality of climate change and its humanitarian 
consequence. In turn, these actions allow them to take a more sovereigntist stand, in the sense that they shy away from their responsibility for climate change's consequences.

These political consequences are intertwined with the analytical consequences of not recognizing the relation between climate change and migration. One of the key complications that scholars face in the climate-migration conundrum is to challenge a purely formalist analysis of the issue. This formalist standpoint takes the lack of a formal definition of climate migration in International Law, and consequently the lack of official data numbering on climate migrants as forcibly displaced people (BIERMANN; BOAS, 2010; RAMOS, 2011; CLARO, 2015), as an impeditive for studying and interpreting it as relevant for research (ATAPATTU, 2020).

The lack of international protection, as Biermann and Boas (2010, p. 74) state, leaves "the main responsibility [for climate migrants to be] placed with their home countries", even in cases where the country of origin has limited or no responsibility for the causes of displacement. Climate change is unevenly distributed among regions and income groups globally and has increasingly become a driving factor for advancing migratory flows. Since those who need to migrate are often not responsible for anthropogenic climate change, as, in general, their lifestyles produce very little or no anthropogenic greenhouse effect emissions, it is a common argument that the industrialized countries must undertake the greatest part of the effort to reduce gas emissions.

However, often these same countries are not engaged in efforts against climate change, as industrialized countries are also comparatively less affected by global warming (GEMENNE, 2017; VINKE, 2020). For Biermann and Boas (2010), a set of governance arrangements and a consensual definition of who is a climate migrant are tantamount to deal with the flow of climate-related displaced people, in the sense that these measures locate most of the economic and humanitarian burden associated with climate migration within industrialized countries, which are arguably more responsible for climate change.

Central America has suffered directly from the effects of climate change; in parallel, we are increasingly witnessing an upsurge of the number of immigrants from the region into the United States. We must surpass the strictly formalist standpoint that these migrants are not 
being forced to displace due to climate change solely because there is no clear, formal, and established final recognition of their status. Then, it would be attainable to discuss the U.S. historical, moral, and even legal responsibility for climate migrants from Central America.

The U.S' historical responsibility is related to its trajectory of emissions, as the global climate crisis is heavily influenced by the U.S. industrialization process and uncontrolled greenhouse gas emissions throughout its history (THOMPSON, 2017). The U.S. is responsible for the largest amount of $\mathrm{CO} 2$ emissions in the world - one of the major contributors to advancing climate change (INTEGRATED CARBON OBSERVATION SYSTEM - ICOS, 2020). Once the effects of these gas emissions do not cease at the countries' borders, the consequences of their actions extend to other nations. Thus, the responsibility for climate migrants shall lie with developed countries, such as the United States, for their past and present actions, allowing the entry and reception of climate migrants and refugees while also participating in international efforts to fund adaptation and reallocation initiatives.

The U.S. moral responsibility for climate migrants from Central America may rest on the fact that climate change is a collective problem - and thus a matter of concern and responsibility of different actors (each contributing very differently to the crisis). The U.S., a developed and industrialized country, has ways of providing aid and receiving climate migrants as very few countries do - for example, by adopting domestic policies, cooperating multilaterally, or even leading the climate regime. Climate justice campaigners have highlighted the differences between contributions and impacts among different populations and that the most vulnerable politically marginalized populations suffer the most (MATTAR; MBAKWEM, 2018). Climate change is a global challenge and, as such, it affects all parts of the globe, albeit in different ways; in the same manner, different groups also have different capabilities to deal with it (NAWROTZKI, 2014). The principle of "Common But Differentiated Responsibilities", a pillar of the climate regime, aims to deal with this international disparity.

Climate migration is a matter of global responsibility, and the major emitters must lead the assistance:

Communities that contribute disproportionately to global climate change through their carbon consumption are not only complicit in the dislocation of millions, they are also knowingly responsible for the enhancement of human suffering in their 
claims to limited moral political responsibility for the alleviation of the hardships experienced by growing numbers (SKILLINGTON, 2017, p. 163).

The United States, in particular Trump's administration, neither recognizes climate change and its consequences nor takes responsibility for climate migration ${ }^{9}$. As a candidate, Trump expressed disbelief about the reality of climate change, pledged to repudiate the Paris Accord, and repealed Obama's signature to the Clean Energy Plan to curb greenhouse gas emissions. During his first year as president, he made cutbacks of about $\$ 100$ million in spending on climate change research programs (CHIRICO, 2017). Although the United States is facing the consequences of environmental changes, Trump's administration has steadily denied global warming and its aftermath ${ }^{10}$. It publicly dismissed in late 2018 a warning report on climate change made by thirteen U.S. federal agencies saying he does not "believe in it" (BLITZER, 2019a).

In addition to the historical and moral responsibilities, there are discussions addressing states' legal responsibility due to the effects of climate change (ATAPATTU, 2020; LANGE, 2010; TOL, 2004). International law lacks explicit and formal obligations on the impacts generated by climate change, having no legal mechanism that forces states to provide legal status to people who enter the territory due to the effects of climate change. However,

9 One of the particularities of Trump's tenure is a contradictory posture of denying climate change impacts on Central American migration (U.S. CONGRESS, 2019b) and having one of the largest populations of domestically displaced people in the world (HAUER, 2017; IDMC, 2020). A paper published in Nature Climate Change (HAUER, 2017) predicted that 13 million U.S. citizens would be displaced by sea-level rise until the end of the century, with more than $86 \%$ of the U.S. cities being affected by climate migration at some level. And, while denying it, the U.S. Government has already spent billions to adapt to climate change, raising the streets of Miami meters above sea-level, or building a shield to prevent the waters from flooding the lower parts of Manhattan, a multi-million project called "BIG U" (MILMAN, 2018; SAINTOURENS, 2019). Despite the pharaonic scale of these adaptation projects, sea-level rise is already displacing North-Americans from coastal states such as Florida, while droughts in western states are becoming more common and extreme events such as hurricanes are expected to increase in both frequency and intensity (MILMAN, 2018; IDMC, 2020).

10 In 2019, two denunciations were made in relation to Trump's administration and its climate denial. The first occurred in March, in the face of a study by the US Geological Survey (USGS), which showed that "climate change can have a devastating effect on the California economy" (WALDMAN, 2019). In presenting this study, Trump officials excluded references to climate change from communiqués, only showing how the study served to plan infrastructure investments along the coast. Again, in September of the same year, email leaks suggested the State Department's Bureau of Population, Refugees, and Migration (PRM) had pressured IOM to remove references to climate change from the organization's documents, otherwise risking losing PRM funding (STOAKES, 2019). These denunciations make it clear how, in addition to denying the existence of climate change, Trump tries to intervene by censoring entities and scientific studies so that he cannot be held responsible 
some authors have argued that international agreements, such as the UNFCCC and the human rights regime, could provide an International Law framework for protecting climate migrants (ATAPATTU, 2020).

Climate migration happens due to an increase of environmental stressors due to climate change, which cause the deterioration of livelihoods. These adverse impacts on human needs can be framed as violations of human rights, as they affect the right to life itself (MCINERNEY-LANKFORD, 2009). The idea that states' right of controlling borders and denying people entrance into their territory - a typical exercise of sovereignty - should be attenuated is developed mainly considering climate migration in Small Islands Developing States, as it allows groups affected by climate change to self-determine their destiny and to migrate in order to survive and exercise their right to life (WILLCOX, 2012).

The Paris Agreement, adopted in 2015, was the first climate agreement to explicitly mention that States should consider their obligations on the rights of migrants (preamble), although it does not mandate the protection and assistance of migrants.

The Global Compact for Safe, Orderly and Regular Migration, adopted in Morocco in 2018 and further endorsed by UN members, is the most prominent deal to formally recognize climate change as a possible driver for migration, stating that forced displacement "may result from sudden-onset and slow-onset natural disasters, the adverse effects of climate change, environmental degradation [...]" (GLOBAL COMPACT FOR MIGRATION, 2018, p. 9). While the Compact was seen as progressive and an opportunity to improve the governance of migration (ATAPATTU, 2020), the U.S. administration withdrew early from international negotiations, hence rendering it more fragile since the North American country is one of the largest receivers of asylum seekers. The U.S. Congress justified the withdrawal by stating that the agreement constrained their ability to make guidelines and decisions for the interests of their nation, especially on the matter of child detention and the differentiation between legal and illegal migration. They alleged the right to detain minor migrants and ensure developed countries could restrict and diminish pathways for legal migration whenever in their best interest (U.S. CONGRESS, 2019a). Some countries, such as 
Australia and Brazil, followed the U.S. lead and withdrew from the discussions in later 2018 and 2019.

In January 2020, the United Nations Human Rights Committee analyzed a petition of a person seeking protection from the effects of climate change and determined that people who have sought asylum due to climate-related threats cannot be deported (UNITED NATIONS, 2020). It is the first decision by a UN human rights treaty body that relates nonrefoulement obligations and climate migration, and it may reframe the interpretation concerning the recognition of climate refugees.

Despite that, because there is not yet a bidding instrument or a mandatory norm defining the obligation of accepting climate migrants, states tend to frame them as economic migrants (ATAPATTU, 2020). The use of framings of economic and labor migration are often employed by receiving states to depoliticize migration flows "in an abstract manner, as if it did not refer to real people" (ORTEGA, 2016, pg. 9). As such, they impose significantly restricted regulations depending on the country of origin, as can be illustrated by looking at the reception of European and Latin American migrants in the U.S. ${ }^{11}$

According to McAdam (2011), states are reluctant to open their borders to climate migrants because they fear it would attract many communities from vulnerable places and establish some duty under customary international law. By undertaking this position, however, the human rights of these migrants are violated, considering the elements that indicate that the Central American Caravans include groups of migrants that have decided to leave their territory because of habitability' threats caused by climate change and the impossibility of the exercise of fundamental human rights, such as dignity and selfdetermination.

Regarding the development of restrictive migration policies, the United States avoids its international responsibility by denying protection for migrants, pretending to have no influence on climate migration. However, U.S. avoidance should not prevent scholars from

11 In September 2019, U.S. Senator Edward J. Markey introduced legislation S2565 "to establish a Global Climate Change Resilience Strategy, to authorize the admission of climate-displaced persons". According to Markey, "We cannot allow climate-displaced persons to fall through the cracks in our system of humanitarian protections simply because they do not meet the definition of refugee. America has the capacity and should be the global leader in resettlement, and that means equally responding to climate displaced individuals as we do refugees." (EDMARKEY, 2019). 
considering the climate-migration nexus over the Central American Caravans in its complexity: climate change is forcing people to move, and looking at Central American migrant caravans can shed some light on how. We do not intend to claim that there is a single causal link between climate change and displacement. However, by reflecting upon this case of analysis, we make a contribution for the study of how the economic and humanitarian burdens involved in climate migration governance are unequally distributed among states - and which are the political and analytical consequences derived if one overlooks the climate-displacement nexus.

\section{FINAL REMARKS}

Climate change is pushing people to migrate; yet, it is overlooked as a driver for forced displacement in Central America. It plays a significant role as a push factor for migration in the region, either directly (i.e., by forcing people to migrate due to drought or disasters) or indirectly (i.e., by reducing crop productivity and water availability or changing weather patterns).

Although it would be incorrect to affirm that climate change is the sole cause of migration from Central America, the available data indicate that it can be considered as a significant cause of displacement. There are many catastrophic and slow-onset climate change events occurring globally, which can influence flows of domestic and international migration. Nevertheless, differently from conventional refugees and political asylees, it is hard to quantify climate migration in its entirety. One of the difficulties for this is due to the lack of data collection on this displacement, and this lack is further explained by the current gaps that climate migrants face in International Law (ATAPATTU, 2020; IOM, 2020).

We argued in this paper that, by analyzing migration and climate data reports (e.g., ICOS, 2020; ECKSTEIN; HUTFILS; WINGES, 2019; IDMC, 2020; RIGAUD et al., 2018; RAINFOREST ALLIANCE, 2019), one can attain how climate change is a relevant push factor for people to migrate in Central America. We have delved into this argument by investigating the political 
and analytical consequences of overlooking developed states' responsibility in general, and U.S. responsibility in specific, concerning climate migration.

We pointed also that despite their conceivably international responsibility, the U.S. takes advantage of the lack of international consensus and definition of climate migration to deny entry and to refuse protection to climate migrants, mischaracterizing them as conventional economic migrants. Climate change is caused mainly by greenhouse gas emissions and the U.S. is one of the largest polluters, having impacted more on global climate change than any other country (ICOS, 2020). However, the refusal of characterizing Central American migration flows as induced by climate change allows the U.S. to pursue a more sovereigntist position - to the detriment of assuming its international responsibility for climate change and climate migrants. Furthermore, the U.S. historical immigration policy has a sovereigntist approach that is restrictive and discretionary when dealing with migrants from Latin America.

The complex relationship between migration and climate change, among other things, effects the lack of a formal definition of climate migration within international law. This definitional gap, in turn, results in the absence of official data on climate migrants as forcefully displaced persons. Political and analytical consequences can be drawn because of this. The former is reflected in how, by mistakenly categorizing climate migration as conventional economic migrants, the reality of climate change and its humanitarian consequences are overlooked - thus allowing states to avoid their international responsibilities. The latter is indicated by how some scholars analyze complex phenomena through a strictly formalist standpoint. These consequences may hinder how we look at climate migration because, regardless of formalist conceptualizations, climate change affects people's decision to move. Reflecting upon the Central America migrant caravans may shed some light on how states are dealing (or not) with climate mobility, and which are some of the consequences of overlooking the climate-displacement nexus. 


\section{REFERENCES}

ABDENUR, Adriana. Climate Migration Hotspots in Mexico and Central America. Instituto Igarapé. 2019. Available at: <https://igarape.org.br/climate-migration-hotspots-in-mexicoand-central-america/> Accessed on June 10, 2019.

ALTAMIRANO, TEÓFILO. Refugiados Ambientales: Cambio Climático y Migración Forzada. Lima: Fondo Editorial de la Pontifica Universidad Católica del Peru, 2013.

ATAPATTU, Sumudu. Climate change and displacement: protecting "climate refugees" within a framework of justice and human rights. Journal of Human Rights and the Environment, v. 11, n. 01, p. 86-113, 2020. DOI: 10.4337/jhre.2020.01.04

BETTS, Alexander. Forced Migration and Global Politics. Chichester: Wiley-Blackwell, 2009.

BIERMANN, Frank; BOAS, Ingrid. Preparing for a warmer world: Towards a global governance system to protect climate refugees. Global Environmental Politics, v. 10, n. 01, p. 60-88, 2010. DOI: 10.1162/glep.2010.10.1.60.

BLITZER, Jonathan. How Climate Change Is Fuelling the U.S. Border Crisis. New Yorker. 2019a Available at: <https://www.newyorker.com/news/dispatch/how-climate-change-is-fuellingthe-us-border-crisis> Accessed on June 26, 2019.

. Trump's Cycle of Self-Sabotage at the U.S. Border. New Yorker. 2019b.

<https://www.newyorker.com/news/news-desk/trumps-cycle-of-self-sabotage-at-the-usborder> Accessed on June 26, 2019.

BOAS, Ingrid; KLOPPENBURG, Sanneke; VAN LEEUWEN, Judith; LAMERS, Machiel. Environmental mobilities: an alternative lens to global environmental governance. Global Environmental Politics, v. 18, n. 04, p. 107-126, 2018. DOI: 10.1162/glep_a_00482.

BOAS, Ingrid; FARBOTKO, Carol; ADAMS, Helen; STERLY, Harald; BUSH, Simon; VAN DER GEEST, Kees; WIEGEL, Hanne; ASHRAF, Hasan; BALDWIN, Andrew; BETTINI, Giovanni; BLONDIN, Suzy; DE BRUIJN, Mirjam; DURAND-DELACRE, David; FRÖHLICH, Cristiane; GIOLI, Giovanna; GUAITA, Lucia; HUT, Elodie; JARAWURA, Francis X.; LAMERS, Machiel; LIETAER, Samuel; NASH, Sarah L.; PIGUET, Etienne; ROTHE, Delf; SAKDAPOLRAK, Patrick; SMITH, Lothar; FURLONG, Basundhara Tripathy; TURHAN, Ethemcan; WARNER, Jeroen; ZICKGRAF, Caroline; BLACK, Richard; HULME, Mike. Climate Migration Myths. Nature Climate Change, v. 09, n. 12, p. 901-903, 2019. DOI: 10.1038/s41558-019-0633-3.

CHANG-MUY, Fernando; GARNICK, Adam. Why Trump's Cruelty Doesn't Deter Migrants. The New York Times. Opinion. 2019. <https://www.nytimes.com/2019/07/29/opinion/asylumtrump-guatemala-honduras.html> Accessed on July 26, 2019.

CHIRICO, Francesco. The Challenges of Climate Change, migration and conflict in pursuit of the Sustainable Development Goals: A call to responsible and responsive policy makers. 
Journal of Health and Social Sciences, v. 2, n. 02, p. 137-142, 2017. DOI: $10.19204 / 2017 /$ thch1.

CLARO, Carolina de Abreu Batista. A Proteção dos "Refugiados Ambientais" no Direito Internacional. 2015. PhD dissertation (Doctorate of International Law), Universidade de São Paulo, 2015.

DICKERSON, Caitlin. 10 Years Old, Tearful and Confused After a Sudden Deportation. The New York Times, 20 May 2020. H<ttps://www.nytimes.com/2020/05/20/us/coronavirusmigrant-children-unaccompanied-minors.html> Accessed on May 30, 2020.

DUN, Olivia; GEMENNE, François. Defining 'environmental migration'. Forced Migration Review, v. 31, p. 10-11, 2008.

ECKSTEIN, David; HUTFILS, Marie-Lena; WINGES, Maik. Global Climate Risk Index 2019: Who Suffers Most from Extreme Weather Events? Weather-related Loss Events in 2017 and 1998 to 2017. Berlin: German Watch. 2019.

<https://germanwatch.org/sites/germanwatch.org/files/GlobalClimateRiskIndex2019_2.pdf> Accessed on July 27, 2019.

ECONOMIC COMMISSION FOR LATIN AMERICA AND THE CARIBBEAN - ECLAC. Atlas of migration in Northern Central America. Santiago: ECLAC. 2018.

<https://repositorio.cepal.org/bitstream/handle/11362/44288/1/S1801071_en.pdf.> Accessed on July 15, 2019.

EDMARKEY. Senator Markey Introduces First of Its Kind Legislation to Address Climate "Refugee" Crisis. 2019. <https://www.markey.senate.gov/news/press-releases/senatormarkey-introduces-first-of-its-kind-legislation-to-address-climate-refugee-crisis $>$ Accessed on May 30, 2020.

EWING, Walter. Opportunity and Exclusion: A Brief History of U.S. Immigration Policy. Washington: American Immigration Council, 2012.

<https://www.americanimmigrationcouncil.org/sites/default/files/research/opportunity_ex clusion_011312.pdf> Accessed on July 29, 2019.

FOOD AND AGRICULTURE ORGANIZATION - FAO. Chronology of the Dry Corridor: The impetus for resilience in Central America. 2017. <http://www.fao.org/inaction/agronoticias/detail/en/c/1024539/> Accessed on August 11, 2019.

GARDNER, Hall. World War Trump: the risks of America's new nationalism. New York: Prometheus Books, 2018.

GEMENNE, François. The Refugees of the Anthropocene. In: MAYER, B.; CRPEPEAU, F. (eds). Research Handbook on Climate Change, Migration and the Law. Cheltenham: Edward Elgar, 2017, p. 394-404. 
GLOBAL COMPACT FOR MIGRATION. The Global Compact for Safe, Orderly and Regular Migration. Morocco: The United Nations, 2018.

HAUER, Mathew E. Migration induced by sea-level rise could reshape the US population landscape. Nature Climate Change, v. 7, p. 321-325, 2017. DOI: 10.1038/nclimate3271.

INTEGRATED CARBON OBSERVATION SYSTEM - ICOS. 2020 Global Carbon Budget 2020. $<$ https://www.icos-cp.eu/science-and-impact/global-carbon-budget/2020> Accessed on 05 June 2021.

INTERGOVERNMENTAL PANEL ON CLIMATE CHANGE - IPCC. Climate Change 2007: The Physical Science Basis. Contribution of Working Group I to the Fourth Assessment Report of the Intergovernmental Panel on Climate Change. Solomon et al. (orgs.). Cambridge:

Cambridge University Press, 2007.

INTERNAL DISPLACEMENT MONITORING CENTER - IDMC. Global Report on Internal Displacement 2020. Geneva: Norwegian Refugee Council, 2020.

INTERNATIONAL ORGANIZATION FOR MIGRATION - IOM. What do we know about data on environmental migration? Global Migration Data Analysis Center - GMDAC, 2019.

<https://vimeo.com/305714985> Accessed on May 4, 2019.

International Law: Glossary on Migration. 2019.

<https://publications.iom.int/system/files/pdf/iml_34_glossary.pdf> Accessed on July 18, 2021.

Environmental Migration. Migration Data Portal. 2020.

<https://migrationdataportal.org/themes/environmental_migration> Accessed on May 30, 2020.

JUBILUT, Liliana Lyra; RAMOS, Érika Pires; CLARO, Carolina de Abreu Batista; CAVEDONCAPDEVILLE; Fernanda De Salles (orgs). Refugiados Ambientais. Boa Vista: Editora da Universidade Federal de Roraima, 2018.

KUCZERA, Reiss. U.S. Refugee Policy in the Era of Homeland Security: A Comparative Government Analysis. Master Thesis, Naval Postgraduate School, 2017.

LANGE, Holly D. Climate Refugees Require Relocation Assistance: Guaranteeing Adequate Land Assets Through Treaties Based on the National Adaptation Programmes of Action. Washington International Law Journal, v. 19, n. 03, p. 613-640, 2010.

LEE, Michelle Y. H. Donald Trump's false comments connecting Mexican immigrants and crime. Washington Post, 08 July 2015. <http://www.washingtonpost.com/news/factchecker/wp/2015/07/08/donald-trumpsfalse-comments-connecting-mexican-immigrantsandcrime/?utm_term=.9d204ef42151.> Accessed on July 26, 2019. 
MARKHAM, Lauren. How climate change is pushing Central American migrants to the US. The Guardian. 2019. <https://www.theguardian.com/commentisfree/2019/apr/06/usmexico-immigration-climate-change-migration> Accessed on July 28, 2019.

MATTAR, Sennan; MBAKWEM, Enyinnaya. Climate migration: the emerging need for a human-centered approach. In: JAFRY, T. Routledge Handbook of Climate Justice. London: Routledge, 2018, p. 479-493.

MCADAM, Jane. 2011. Environmental Migration. In: BETTS, A. Global Migration Governance. Cambridge: Oxford University Press, 2011, p. 152-187.

MCINERNEY-LANKFORD, Siobhan. Climate Change and Human Rights: An Introduction to Legal Issues. Harvard Environmental Law Review, v. 33, p. 431-437, 2009.

MÉNDEZ, J. C. “La Cooperación Sur-Sur y El Abordaje Del Desplazamiento Transfronterizo Causado Por Desastres y Cambio Climático: Experiencias En América Latina y El Caribe." Monções: Revista de Relações Internacionais da UFGD, v. 8 n. 16, p. 42-71, 2020.

MILMAN, Oliver. "We're moving to higher ground": America's era of climate mass migration is here. The Guardian. 2018.

<https://www.theguardian.com/environment/2018/sep/24/americas-era-of-climate-massmigration-is-here> Accessed on July 28, 2019.

MILMAN, Oliver; HOLDEN, Emily; AGREN, David. The unseen driver behind the migrant caravan: climate change. The Guardian. 2018.

$<$ https://www.theguardian.com/world/2018/oct/30/migrant-caravan-causes-climatechange-central-america> Accessed on July 28, 2019.

MYERS, Norman. Environmental refugees in a globally warmed world. BioScience, v. 43, n. 11, p. 752-761, 1993. DOI: 10.2307/1312319.

NAWROTZKI, Raphael J. Climate Migration and Moral Responsibility. Ethics, Policy \& Environment, v. 1, p. 69-87, 2014. DOI: 10.1080/21550085.2014.885173.

O'CONNOR, Alisson; BATALOVA, Jeanne; BOLTER, Jessica. Central American Immigrants in the United States. Migration Policy Institute. 2019.

<https://www.migrationpolicy.org/article/central-american-immigrants-united-states> Accessed on January 18, 2020.

ORTEGA, Ana. ¿Migración Voluntaria o Expulsión? Una Aproximación a Las Causas y Dinámicas de La Migración Laboral En Honduras. Tegucigalpa: Friedrich Ebert Stiftung, 2016.

PIERCE, Sarah; BOLTER, Jessica; SELEE, Andrew. U.S. Immigration Policy under Trump: Deep Changes and Lasting Impacts. Washington: Migration Policy Institute, 2018. 
PIGLIUCCI, Caley. The Forgotten Migrants of Central America. Inter Press Service. 2019. <http://www.ipsnews.net/2019/06/forgotten-migrants-central-america/> Accessed on July 20, 2019.

POWASKI, Ronald E. Ideals, Interests, and U. S. Foreign Policy from George H. W. Bush to Donald Trump. Ashland: Palgrave Macmillan, 2019.

RAINFOREST ALLIANCE. Mexico and Central America: on the front lines of conservation. 2019. <https://www.rainforest-alliance.org/regions/mexico-central-america> Accessed on August 05, 2019.

RAMOS, Érika Pires. Refugiados Ambientais: em busca de reconhecimento pelo direito internacional. 2011. PhD dissertation (Doctorate of Law), Universidade de São Paulo, 2011.

RIGAUD, Kanta Kumari; DE SHERBININ, Alex; JONES, Bryan; BERGMANN, Jonas; CLEMENT, Viviane; OBER, Kayly; SCHEWE, Jacob; ADAMO, Susana; MCCUSKER, Brent; HEUSER, Silke; MIDGLEY, Amelia. Groundswell: Preparing for Internal Climate Migration. Washington: The World Bank, 2018.

SAINTOURENS, T. Aux États-Unis aussi il y a des réfugiés climatiques. Usbek \& Rica. 2019. $<$ https://usbeketrica.com/article/aux-etats-unis-aussi-refugies-climatiques> Accessed on May 10, 2019.

SIEFF, Kevin; SHERIDAN, Mary Beth. U.S., Mexico pledge billions to reduce migration from Central America. The Washington Post, 18 December 2018. <https://wapo.st/2L7YGJb> Accessed on Jul 10, 2019.

SIGELMANN, Laura. The Hidden Driver: Climate Change and Migration in Central America's Northern Triangle. American Security Project. 2019.

SIVISACA, L.; DEICY, A. C.; MONTES, I. G.; ROBALINO, J. H. "Eventos Climáticos Extremos y Migración Interna En Guatemala, Un Análisis Basado En Percepciones de Expertos." CIENCIA Ergo-Sum, Toluca, v. 22, n. 1, p. 35-44, 2015.

SKILLINGTON, Tracey. Climate Justice and Human Rights. New York: Palgrave, 2017.

STERN, N. H. The economics of climate change: The Stern Review. Cambridge: Cambridge University Press, 2007.

STOAKES, Emanuel. Leak suggests UN agency self-censors on climate crisis after US pressure. The Guardian. 11 September 2019. <https://www.theguardian.com/globaldevelopment/2019/sep/11/leak-suggests-un-agency-self-censors-on-climate-crisis-after-uspressure > Accessed on May 30, 2020.

THOMPSON, J. Historical Responsibility and Climate Change. In: MEYER, L. H.; SANKLECHA, P. (eds.). Climate Justice and Historical Emissions. Cambridge: Cambridge University Press, p. 
46-60, 2017.

TOL, Verheyen. State responsibility and compensation for climate change damages - a legal and economic assessment. Energy Policy, v. 32, p. 1109-1130, 2004. DOI: 10.1016/S03014215(03)00075-2.

TRUMP, Donald. Donald Trump Presidential Campaign Announcement. 2015. <https://www.c-span.org/video/?326473-1/donald-trump-presidential-campaignannouncement\&start=2868> Accessed on July 28, 2019.

TRAROOR, Ishaan. How Trump's border crisis is driven by climate change. The Washington Post. 2019. <https://www.washington post.com/world/2019/04/16/how-trumps-bordercrisis-is-driven-by-climate-change/?noredirect=on> Accessed on July 28, 2019.

UNITED NATIONS HIGH COMMISSIONER FOR REFUGEES - UNHCR. Global Trends: Forced Displacement in 2019. New York, 2020.

UNITED NATIONS. UN human rights ruling could boost climate change asylum claims. UN News. January 21 2020. <https://news.un.org/en/story/2020/01/1055671> Accessed on January 21, 2020.

UNITED STATES CONGRESS. The Global Compact on Migration (GMC) and U.S. policy. 2019a. <https://fas.org/sgp/crs/row/IF11003.pdf> Accessed on August 26, 2019.

Recent Migration to the United States from Central America: Frequently Asked Questions. 2019b. <https://fas.org/sgp/crs/row/R45489.pdf> Accessed on July 29, 2019.

\section{U.S. CUSTOMS AND BORDER PROTECTION. U.S. Border Patrol Southwest Border}

Apprehensions by Sector. <https://www.cbp.gov/newsroom/stats/southwest-land-borderencounters/usbp-sw-border-apprehensions> Accessed on 03 June, 2021.

VINKE, Kira. Unsettling Settlements - Cities, Migrants, Climate Change: Rural-Urban Climate Migration as Effective Adaptation? Zürich: Lit Verlag GmbH\&Co. KG Wien, 2020.

WAGTENDONK, Anya Van. A controversial deal between the US and Guatemala could reshape the asylum process. Vox. 2019.

<https://www.vox.com/2019/7/27/8932786/guatemala-us-third-safe-country-dealimmigration-asylum-process $>$ Accessed on 28 July, 2019.

WALDMAN, Scott. Trump officials deleting mentions of "climate change" from U.S. Geological Survey press releases. Science. 8 July, 2019.

$<$ https://www.sciencemag.org/news/2019/07/trump-officials-deleting-mentions-climatechange-us-geological-survey-press-releases> Accessed on May 30, 2020.

WEISS, Laura. Trump's Threats Won't Make Mexico and Guatemala "Safe Third Countries". World Politics Review. 26 July, 2019. <https://www.worldpoliticsreview.com/trend- 
lines/28073/trump-s-threats-won-t-make-mexico-and-guatemala-safe-third-countries> Accessed on July 28, 2019.

WERNICK, Adam. Climate change is the overlooked driver of Central American migration. Public Radio International. 2019. <https://www.pri.org/stories/2019-02-06/climate-changeoverlooked-driver-central-american-migration> Accessed on August 7, 2019.

WILLCOX, Susannah. A Rising Tide: The Implications of Climate Change Inundation for Human Rights and State Sovereignty. Essex Human Rights Review, v. 9, n. 01, p. 1-19, 2012.

WORLD FOOD PROGRAMME - WFP. Food Security: Why people flee and the impact on family members. Rome: 2017. <https://docs.wfp.org/api/documents/WFP0000022124/download/?_ga=2.85460124.46423775.15404020161767178983.1540402016> Accessed on July 25, 2019. 